\title{
The Application of Educational Games in College English Teaching
}

\author{
Ying Luo ${ }^{1, ~ a ~, ~ H a o ~} \mathrm{Lu}^{2, \mathrm{~b}}$ \\ ${ }^{1}$ Education School, Jiangxi Science \& Technology Normal University, Nanchang, China \\ 2 Jiangxi Vocational \& Technical College of Information Application, Nanchang, China \\ amooonly@126.com; 'lh880223@163.com
}

Keywords: educational games; English teaching; application

\begin{abstract}
With the continuous development of social economy, education is also closely following the development trend of the times to change constantly. In the teaching process, adhere to the students as the main body, innovate the teaching methods, put forward new teaching ideas, and cultivate and improve the students' comprehensive ability in all aspects. In such great era of education, English is also innovate teaching methods constantly, such as letting the educational games join the teaching process to stimulate the students' interest and improve classroom efficiency. The paper mainly analyzes the educational value of educational games in English teaching and puts forwards the concrete application methods on this basis to improve the efficiency of students' English learning.
\end{abstract}

\section{Introduction}

With the continuous change of education, some new teaching methods are constantly introduced into classroom of various subjects. English, as a foreign language, is difficult due to its own characteristics. In addition of different thinking ways of college students, teachers often fail to achieve the desired teaching results in the process of teaching. In this way, teachers can not teach students knowledge while students lose their enthusiasm of learning English. Nowadays, the new educational reform puts forward the "educational games" in college English teaching. The teaching methods can make English classes achieve the best possible results. In the following, the paper will discuss the application of educational games in college English teaching.

\section{The present situation of college English teaching}

The difficulty of English is big and the enthusiasm of students is low. The scope of knowledge in college English is relatively broad, including grammar, vocabulary, translation, writing, and so on. The students can not grasp those quickly and often have to learn new knowledge of English when cloudy. In this way, more and more English knowledge will be accumulated which is not fully grasped. Of course, students' enthusiasm will gradually decline and some students even produce weariness, which is not good for English learning. In addition to this situation, the characteristics of college students themselves will also determine low enthusiasm. In colleges, many students only pay attention to their own specialized courses and neglect the importance of learning English. Unlike other subjects, English is a rather boring course, so students have less motivation.

Traditional teaching methods are still adopt by English teachers. This teaching method can not improve students' interest and often lead to the dull and boring classroom atmosphere. Students will 
not participate in English learning actively and consciously. Traditional teaching methods often ignore the subject position of students and let them become listeners. The method is not good for students to learn English and it is also harmful to the teaching.

\section{The importance of educational games in college English teaching}

Games, as a relaxing and enjoyable way of leisure for people, is helpful for intellectual development. In the games, students always have strong curiosity and thirst for knowledge. Educational games is a new type of teaching method to develop education through games, which can promote the achievement of learning effectively. For the official explanation of educational games, we can see from two aspects. On the broad sense, students use the knowledge of various disciplines to carry out competition practice for the purpose of wining. On the narrow sense, a variety of games created for the development of students' knowledge, skills and intelligence, such as electronic software.

Learners stimulate internal learning motivation consciously. Compared with the learning on the usual sense, the biggest difference of the games is the internal power. In everyday English teaching, the key problem is not lack of learning ability, but the learning interest. Teachers often do everything possible to stimulate students' interest. However, such efforts are often difficult to get return. In the face of difficult games, the players are holding extraordinary enthusiasm. The reason why the games have such strong attraction lie in the incentive mechanism in the games. In the games, the players have clear goal, or win the game, or complete a certain task with other players, or win the reputation, loot rewards, etc. those clear goals cause the players the demand and internal motivation of playing games directly. By taking the mechanism generated by the interest and motivation of the games into English teaching, the learning agent will take the initiative to explore some new knowledge for experiencing the learning process similar to the games, so as to fully and autonomously explore the subjective initiative and learning potential, constantly activate the motivation of English learning and improve the level of English learning.

Learners' English proficiency is truly improved. Player can choose different ways and plans to complete the task. Because sub goals and problems of each solution have their own focus and characteristics, the players with different knowledge backgrounds can determine different solutions according to their own level and preferences, thus helping to effectively implement the students in accordance with their aptitude.

\section{The application of educational games in college English teaching}

The application of educational games in word learning. In English learning, the word is the basis and a standard to measure the students' English level. But because the word learning is boring, the learning style adopt by most students is by rote, which is easy to make students lose curiosity. When they consider the memory method become a burden, they will have very serious weariness. In order to effectively alleviate this situation, we can incorporate educational games into word learning, such as some educational games software about passing a barrier or making a pair. The games are based on the English words, so the students are not only interested in playing, but also create some new ways of playing. Therefore, it will inevitably receive good result if the educational games are used in English word teaching.

The application of educational games in listening teaching. Listening is the key to learn English, so the way of listening teaching has important influence on students' listening ability. The effect of traditional listening teaching is not very good. So applying the educational games in listening teaching to let the students play a role and exchange with simple dairy English through the creation of specific scenes of life, which can not only help the students to review and consolidate the 
vocabulary, but also can arouse the students' interest to improve their English listening level. In addition, students' autonomous learning ability and innovation ability are also enhanced.

The application of educational games in English grammar. The goal of English teaching is to improve the students' English competence on the basis of theoretical knowledge such as English words and grammar. Therefore, English teaching is to enable students to apply what they have learned and to let students understand how English words change in different parts of speech and tense. English grammar teaching needs to exercise and improve students' application ability, so it is very necessary to apply educational games in English grammar. The English grammar learning is boring and has many fixed sentence patterns, so the application of educational games can make the boring grammar learning alive and smart. In the process of teaching, teachers need to pay attention to different game setting according to different content, so as to fully stimulate the students' desire for knowledge and develop students' independent learning ability.

The application of educational games in pronunciation. Pronunciation teaching is mainly to train students' speaking ability, which is very important in English teaching. At present, the majority of English pronunciation teaching methods are the tape, which is easy to disperse the students' attention, so the teaching effect is not obvious. In the teaching of this link, teachers can make use of inquiry educational games to set the game through multimedia and assign tasks to students. Inquiry game thinking is helpful to stimulate students' learning motivation, cultivate students' learning interest, and let students realize the fun of English learning in the process of independent inquiry.

The application of educational games in reading. Reading, with strong comprehensiveness, not only requires the students to master the corresponding word and grammar, but also to understand with the actual life. Therefore, educational games can be applied into English reading teaching through animation and video to help the students to understand the articles, to improve their reading ability and to enhance the effect of English classroom teaching.

\section{Summary}

To sum up, it is very necessary to integrate the educational games into college English teaching. It is not only suitable to the new standard, the most important is to make the students have good performance in the mastery of knowledge. It is also feasible to integrate the educational games into college English teaching through appropriate patterns to achieve multiple teaching effects.

\section{References}

[1] Maja Pivec,Olga Dziabenko\&Irmgard Schinner1.Aspects of Game-Based Learning[EB/OL]. http://www.unigame.net/html//Know GBL-2704.pdf.

[2] Feifeng Wang. Study on the application of educational games in higher vocational English[J]. Journal of Social Science of Jiamusi University, 2009(6):166-167.

[3] Chunhui Li. Research on the application of educational games in primary school English teaching[D]. Southwestern University, 2010.

[4] Jing Cheng. Exploration on the mode of integrating educational games into primary English teaching[J]. Campus English, 2015(1).

[5] Xiaohong Hu. Research on the application model of educational games in primary school English Teaching[J]. Campus English, 2016(12).

[6] Lili Huang. The design of application strategy in primary school English teaching[J]. Electronic World, 2012(15):115-116.

[7] Jianping Fu. The application of educational games in primary school English teaching[J]. Campus English, 2015,30:111. 